\title{
PENGARUH STRATEGI PEMBELAJARAN DAN GAYA BERPIKIR TERHADAP HASIL BELAJAR BAHASA INDONESIA
}

\author{
Siti Aisyah Hanim ${ }^{1}$ dan Khairil Anshari ${ }^{2}$ \\ Guru MAN 1 Medan ${ }^{1}$ dan FBS Universitas Negeri Medan ${ }^{2}$ \\ sitiaisyahhanim@gmail.com ${ }^{1}$
}

\begin{abstract}
Abstrak: Penelitian ini bertujuan untuk mengetahui: Hasil belajar bahasa Indonesia siswa yang diajarkan dengan strategi pembelajaran Accelerated Learning lebih tinggi dibandingkan strategi pembelajaran Ekspositori. Hasil belajar bahasa Indonesia siswa yang memiliki gaya berpikir sekuensial konkrit lebih tinggi dibandingkan gaya berpikir sekuensial abstrak., interaksi antara strategi pembelajaran dan gaya berpikir sekuensial terhadap hasil belajar Bahasa Indonesia siswa. Metode penelitian menggunakan quasi eksperimen dengan desain penelitian faktorial $2 \times 2$, sedangkan teknik analisis data menggunakan ANAVA dua jalur pada taraf signifikansi $\alpha=0.05$. Hasil penelitian diperoleh: hasil belajar bahasa Indonesia siswa yang diajarkankan dengan strategi Pembelajaran Accelerated Learning lebih tinggi dibandingkan Strategi Pembelajaran Ekspositori, hasil belajar Bahasa Indonesia siswa yang memiliki gaya berpikir sekuensial konkrit lebih tinggi dibandingkan gaya berpikir sekuensial abstrak dan terdapat interaksi antara strategi pembelajaran dan gaya berpikir terhadap hasil belajar Bahasa Indonesia siswa. Penggunaan Strategi Pembelajaran Accelerated Learning lebih tepat digunakan untuk siswa yang memiliki gaya berpikir sekuensial konkrit dan strategi pembelajaran ekspositori lebih tepat digunakan pada siswa yang memiliki gaya berpikir sekuensial abstrak.
\end{abstract}

Kata Kunci: strategi pembelajaran, gaya berpikir, hasil belajar bahasa indonesia

Abstract: This study aims to determine: Results of studying Indonesian students taught by instructional strategy Accelerated Learning higher than Expository learning strategies. Indonesian learning outcomes of students who have a concrete thinking style sequential higher than sequential abstract thinking styles., The interaction between learning strategies and thinking style sequential against Indonesian student learning outcomes. The research method using a quasi-experimental design with a $2 \times 2$ factorial study, while data analysis techniques using ANOVA two paths at the significance level $\alpha=0: 05$. The results were obtained: learning outcomes Indonesian students diajarkankan strategy Learning Accelerated Learning higher than Learning Strategies Expository, learning outcomes Indonesian students who have a thinking style sequential concrete is higher than the style of thinking sequential abstract and there is interaction between learning strategy and style of thinking the learning outcomes of Indonesian students. Use of Accelerated Learning Strategies Learning more appropriately used for students who have a concrete sequential thinking styles and learning strategies more appropriate expository used on students who have sequential abstract thinking style.

Keywords: learning strategies, thinking styles, learning outcomes Indonesian

\section{PENDAHULUAN}

Pembelajaran ini dilakukan sejalan dengan kurikulum yang ada dan dikembangkan sesuai dengan kebutuhan siswa terhadap pemerolehan ilmu dan kecakapan berbahasa. Tyler (dalam Miller dan Saller, 1985) menjelaskan bahwa pengembangan kurikulum untuk bidang studi apapun harus didasarkan atas empat hal, yaitu : (1) apa tujuan yang hendak dicapai, (2) pengalaman apa yang perlu diberikan untuk mencapai tujuan tersebut, (3) bagaimana mengatur pemberian pengalaman tersebut secara efektif, dan (4) bagaimana mengetahui apakah tujuan tersebut telah dicapai. Tarigan (1991:5) menyatakan bahwa di dalam kurikulum yang ideal sedikitnya mencakup lima hal penting berikut : (1) tujuan, (2) metodologi, (3) pendekatan, (4) urutan, dan (5) bobot. Dengan kata lain, dalam setiap pembelajaran perlu ditentukan tujuan, isi, metode, dan evaluasi.

Banyak faktor yang mempengaruhi rendahnya penguasaan, salah satunya disebabkan karena situasi atau kondisi belajar 
yang menimbulkan ketegangan sehingga mempengaruhi pemerolehan bahasa yang dipelajari. Dalam pengajaran bahasa perlu diperhatikan pendekatan apa yang paling sesuai untuk diberikan pada siswa untuk kegiatan pembelajaran.

Rendahnya perolehan rata-rata hasil belajar siswa di MAN 1 dan MAN 2 Medan patut diduga karena lemahnya pembelajaran bahasa Indonesia, dan kurangnya partisipasi guru dalam merancang dan menerapkan berbagai strategi pembelajaran yang relevan dan sesuai dengan karakteristik peserta didik.

Dengan melihat kondisi tersebut, dibutuhkan peran aktif dan perhatian yang lebih serius oleh berbagai pihak terkait untuk dapat meningkatkan hasil belajar bahasa Indonesia seperti yang diharapkan. Dalam hal ini, guru mempunyai tugas yang sangat berat guna mengatasi persoalan tersebut, karena guru memiliki peran yang sangat strategis dalam kegiatan belajar mengajar. Peran strategis ini adalah mentransformasikan pengetahuan, keterampilan dan nilai-nilai kepada peserta didik. Banyak faktor yang diduga menyebabkan rendahnya kualitas pendidikan, khususnya hasil belajar bahasa Indonesia yang relatif masih rendah. Satu diantaranya adalah rendahnya kualitas pembelajaran. Bila pembelajaran itu dilihat sebagai suatu sistem, maka faktor yang turut mempengaruhi kualitas pembelajaran tersebut harus dipenuhi. Faktor-faktor tersebut antara lain sebagaimana dikemukakan Hamalik (1993), yakni mencakup: (1) input mentah atau siswa, (2) lingkungan instruksional, (3) proses pembelajaran, dan (4) keluaran pembelajaran. Hamalik memandang pembelajaran sebagai suatu sistem, sedangkan Reigeluth (1983) mengemukakan tiga komponen utama dalam pembelajaran yaitu metode, kondisi dan hasil. Hubungan metode, kondisi dan hasil dalam pembelajaran dari sisi variabel satu sama lain saling berpengaruh. Variabel kondisi dan metode merupakan variabel bebas dan kedua variabel ini berinteraksi sehingga menghasilkan efek pada hasil belajar sebagai variabel terikat. Oleh karena itu strategi pembelajaran memiliki kaitan yang sangat erat terhadap hasil belajar, karena kesesuaian dan keefektifan strategi pembelajaran mempengaruhi kualitas dan kuantitas hasil belajar.

Guru tidak bisa meletakkan sepenuhnya penyebab masalah ini pada siswa, karena sesungguhnya gurulah yang sangat berperan dalam menciptakan kualitas belajar siswa. Kenyataan ini tidak bisa dipungkiri mengingat pembelajaran yang diberikan selama ini masih kurang optimal. Faktornya bisa saja karena kualitas guru yang kurang memiliki pengetahuan dan keterampilan terhadap pengetahuan yang akan disampaikan., maupun karena pendekatan yang kurang tepat. Jika hal ini karena faktor pendekatan atau metode, maka guru harus segera memperbaiki bentuk pengajaran yang diberikan. Memang tidak ada satupun bentuk pendekatan atau metode yang paling cocok untuk suatu materi pembelajaran. Setiap metode memiliki kelebihan dan kekurangan masing-masing. Guru dapat mengkombinasikan metode yang akan digunakan sesuai dengan kebutuhan proses belajar mengajar. Penggunaan metode yang tepat akan menghasilkan pembelajaran yang efektif, efisian, dan memiliki daya tarik bagi siswa. (Miarso, 2004).

Untuk mengatasi masalah ini diperlukan suatu strategi pembelajaran yang mampu mengatasi permasalahan dan relevan dengan kondisi siswa. Strategi pembelajaran harus dirancang sedemikian rupa agar sesuai dengan karakteristik siswa dan kondisi pembelajaran. Ada banyak strategi yang dapat digunakan untuk meningkatkan aktivitas belajar yang diduga akan meningkatkan prestasi belajar siswa. Dalam penelitian ini digunakan strategi pembelajaran Accelereted Learning dan strategi pembelajaran Ekspositori.

Reigeluth (1983) mendefenisikan hasil belajar sebagai akibat yang dapat dipakai untuk mengukur kegunaan berbagai macam metode pembelajaran dalam berbagai kondisi. Menurutnya, hasil pembelajaran harus memiliki efektifitas, efisiensi dan daya tarik. Merril (1991) memastikan hasil pembelajaran harus selalu dikaitkan dengan pencapaian tujuan pembelajaran. Terdapat tujuh indikator yang dapat digunakan untuk menetapkan keefektifan suatu pengajaran, yaitu: ( 1) kecerdasan penguasaan perilaku, (2) kecepatan unjuk kerja, (3) kesesuaian dengan prosedur, (4) kuantitas unjuk kerja,( 5) kualitas hasil akhir, (6) tingkat hasil belajar, (7) tingkat retensi. Sementara itu efisiensi pengajaran diukur dengan rasio antara keefektifan dan jumlah waktu yang dipakai siswa dan jumlah biaya pengajaran yang digunakan. Indikator utama dalam mengukur efisiensi diacukan pada waktu, personalia dan sumber belajar yang terpakai. Dengan kata lain, jumlah waktu yang dibutuhkan oleh siswa untuk mencapai tujuan yang telah ditetapkan, jumlah personalia yang terlibat dalam pelaksanaan pengajaran dan penggunaan 
sumber belajar yang dirancang untuk pengajaran harus terhitung dengan cermat. Selanjutnya, berkaitan dengan daya tarik pengajaran dapat diukur dengan mengamati kecenderungan siswa untuk tetap atau terus belajar. Daya tarik pengajaran erat sekali kaitannya dengan daya tarik bidang studi dan kualitas pengajaran.

Gagne (1977) menyatakan ada lima kategori hasil belajar, yaitu: (1) informasi verbal, (2) kemahiran intelektual, (3) pengaturan kegiatan kognitif, (4) sikap, (5) keterampilan motorik. Sementara Romiszowski (1981) mengelompokkan keterampilan ada empat kategori, yaitu : (1) kognitif, berkaitan dengan keterampilan seseorang dalam menggunakan pikiran dalam menghadapi sesuatu, 2) acting berkaitan dengan keterampilan fisik, (3) reacting berkaitan dengan keterampilan berkreasi terhadap situasi atau dapat juga disebut dengan sikap, (4) interaktif, keterampilan seseorang dalam berhubungan dengan orang lain untuk mencapai tujuan komunikasi, persuasif dan pendidikan.

Bloom (dalam Anderson, dkk, 2001) mengklasifikasikan hasil belajar dalam tiga ranah yaitu ranah kognitif, afektif dan psikomotorik. Ranah kognitif terbagi dalam enam tingkatan yaitu ingatan, pemahaman, aplikasi, analisis, evaluasi dan kreativitas. Ranah afektif terbagi menjadi lima tingkatan yaitu penerimaan, penganggapan, penghargaan, pengorganisasian dan penjatidirian. Ranah psikomotorik terbagi menjadi empat tingkatan yaitu peniruan, manipulasi, artikulasi, dan pengalamiahan.

Brown (2000: 93) menyatakan bahwa pembelajaran bahasa dapat menerapkan delapan tipe pembelajaran yang dicetuskan oleh Gagne, yaitu : (1) Signal learning (belajar signal) manusia memberikan respon tersendiri terhadap proses bahasa yang dipelajarinya; (2) Stimulusresponse learning (belajar stimulus respon) melalui proses belajar trial-error siswa akan memperoleh pengalaman berbahasa, misalnya pengucapan bunyi seperti halnya yang dikatakan penutur aslinya; (3) Chaining (rantai/rangkaian) pemerolehan pola-pola bahasa yang terstruktur secara skuens/hierarki; (4) Verbal association (asosiasi verbal) pemerolehan bahasa verbal dan non verbal; (5) Discrimination learning (belajar diskriminasi) kesesuaian dalam pemerolehan dan pembedaan makna kata; (6) Concept learning (belajar konsep) belajar konsep-konsep atau aturan bahasa, seperti sintaksis, morfologi;
Principle learning (belajar prinsip) perluasan dari pembelajaran konsep atau pembentukan system linguistik yang lebih kompleks; (8) Problem solving (pecahan masalah) mengatasi masalah terkait pemerolehan bahasa, baik dari segi linguistik maupun interaksi.

Dalam pembelajaran bahasa, kompetensi merupakan pemerolehan sistem bahasa yang terkait dengan aturan-aturan tata bahasa, kosakata dan kompenen bahasa lainnya. Chomsky dalam Brown (2000) membedakan pemerolehan bahasa antara Performa dan pemahaman. Performa merupakan produksi bahasa meliputi : berbicara dan menulis sedangkan pemahaman meliputi keterampilan mendengar dan membaca.

Lebih lanjut dikemukakan oleh Tarigan (1997) kemampuan berbahasa memiliki empat komponen yang saling berhubungan erat yaitu menyimak, berbicara, membaca dan menulis. Dapat dipahami bahwa hakikat belajar bahasa Indonesia adalah untuk berkomunikasi baik lisan maupun tulis.

Strategi pembelajaran dalam konteks belajar mengajar berarti pola umum perbuatan guru dan murid dalam mewujudkan kegiatan belajar. Dick \& Carey (2005) berpendapat bahwa strategi pembelajaran merupakan satu set materi dan prosedur pembelajaran yang digunakan secara bersama-sama untuk mencapai hasil belajar siswa.

Dick \& Carey (2005) menambahkan bahwa strategi pembelajaran memuat lima komponen utama yaitu: (1) aktivitas pembelajaran pendahuluan, (2) penyampaian informasi, (3) partisipasi peserta didik, (4) tes, (5) kegiatan lanjutan. Selanjutnya Suparman (2001) mendefinisikan strategi pembelajaran sebagai perpaduan dari : (1) urutan kegiatan instruksional, (2) cara pengorganisasian materi pengajaran dan peserta didik, (3) peralatan dan bahan, dan (4) waktu yang digunakan dalam proses pembelajaran. Kedua defenisi yang dikemukakan para ahli tersebut pada prinsipnya lebih menekankan pada aspek komponen dan prosedur pengajaran.

Romizowski (1991) juga berpendapat bahwa strategi pembelajaran merupakan suatu pendekatan menyeluruh yang dapat dibedakan menjadi dua strategi dasar yaitu penjelasan dan penemuan. Kedua strategi ini dapat dipandang sebagai dua ujung yang sejalan dalam suatu kontinum strategi. Hal ini erat sekali kaitannya dengan pendekatan deduktif dimana strategi ini dimulai dengan penyajian informasi mengenai prinsip atau kaidah kemudian diikuti dengan tes 
penguasaan dan penerapan dalam bentuk contoh, sedangkan inquiri (penemuan) didasarkan pada teori belajar pengalaman yang disebut juga teori belajar pengalaman.

Dimyati \& Mudjiono

menjelaskan bahwa untuk mengoptimalkan interaksi antara peserta didik dengan komponen sistem pembelajaran lainnya, tenaga pengajar harus mengkonsistensikan tiap-tiap aspek dari komponen-komponen yang membentuk sistem dan dapat melakukan hal tersebut dengan berbagai siasat. Kegiatan tenaga pengajar mengupayakan konsistensi antara aspek-aspek dari komponen pembentuk sistem pembelajaran dengan siasat tertentu inilah yang disebut dengan istilah strategi pembelajaran.

Strategi pembelajaran dalam konteks belajar mengajar berarti pola umum perbuatan guru dan murid dalam mewujudkan kegiatan belajar. Menurut Hamalik (1993) strategi pembelajaran adalah suatu cara, teknik atau langkah-langkah yang akan ditempuh dalam proses belajar mengajar. Sedangkan Romiszwoski (1981) mengatakan strategi pembelajaran berfungsi sebagai cara menyajikan, (menguraikan, memberi contoh dan memberi latihan) isi pelajaran kepada siswa untuk mencapai tujuan tertentu. Senada dengan itu Surakhmad (1980) juga mengatakan bahwa strategi pembelajaran adalah sebagai cara yang fungsinya sebagai alat untuk mencapai tujuan. Karena merupakan alat untuk mencapai bagaimana sempurnanya materi yang disusun , bagusnya media yang ditampilkan, jika metode yang dipilih tidak tepat maka tujuan belajar itu tidak tercapai secara memuaskan.

Hamzah (2009) Strategi pembelajaran adalah cara-cara yang akan digunakan oleh pengajar untuk memilih kegiatan belajar yang akan digunakan selama proses pembelajaran. Pemilihan tersebut dilakukan dengan mempertimbangkan situasi dan kondisi, sumber belajar, kebutuhan dan karakteristik peserta didik yang akan dihadapi untuk mencapai tujuan pembelajaran.

Dalam proses belajar mengajar diperlukan suatu cara atau strategi untuk mencapai tujuan belajar. Strategi pembelajaran merupakan suatu cara yang dapat membantu tercapainya suatu tujuan dengan mengacu kepada gaya berpikir yang terkendali, seksama dengan menyusun seri-seri pengajaran yang memberikan urutan pengalaman belajar secara bertahap, yang pada akhirnya akan mencapai tujuan yang telah dirumuskan. Dalam konteks belajar mengajar, strategi pembelajaran juga berarti pola umum. Perbuatan guru dan siswa dalam mewujudkan kegiatan belajar.

Strategi itu pada dasarnya dapat dikelompokkkan ke dalam berbagai bentuk. Ditinjau dari segi cara penyajian dan cara pengolahannya, strategi pembelajaran juga dapat dibagi menjadi dua kategori yaitu strategi pembelajaran berpusat pada guru dan berpusat pada siswa. Salah satu strategi pembelajaran yang berpusat pada guru adalah Ekspositori. Sedangkan beberapa strategi yang berpusat pada siswa diantaranya adalah strategi pembelajaran inkuiri, strategi pembelajaran berbasis masalah, strategi pembelajaran kooperatif dan strategi pembelajaran kontekstual.

Selama beberapa tahun terakhir, banyak strategi pembelajaran yang dipercepat yang mulai sering diperbincangkan dan mulai diterapkan di sekolah-sekolah di Indonesia. Sebelumnya strategi serupa juga sudah popular di luar negeri diantaranya adalah Quantum Learning, Quantum Teaching, Super Learning, dan Efficient and Effective Teaching. Strategi pembelajaran ini berkembang didasarkan pada pengetahuan tentang cara kerja otak, cara kerja memori, Neuro linguistik programming, motivasi, konsep diri, kepribadian, perasaan, emosi, metakognisi, gaya belajar, gaya berpikir, multiple intelligence, teknik memori, teknik membaca, mencatat dan teknik belajar lainnya. (Gunawan, 2006:2). Diantara berbagai strategi pembelajaran, strategi Accelerated Learning merupakan salah satu strategi yang relatif baru yang berupaya menemukan cara pengajaran terbaik

Barbara Prashing (2007) Accelarated Learning dikembangkan pada pertengahan 1970 oleh Dr. George Lozanov, seorang psikiater dan pendidik Bulgaria, Dr. G. Lozanov telah membuktikan bahwa proses belajar dapat dipercepat dengan cara tidak memberi sugesti kepada siswa tentang keyakinan-keyakinan yang terbatas.

Menurut Donal Hebb dalam Darmawan (2009:128) ada dua tipe kemampuan intelegensi manusia, Pertama, intelegensi sebagai potensi individu yang harus dikembangkan. Kedua, intelegensi sebagai bentuk tingkat kemampuan dari penampilan atau spesifikasi yang dimiliki individu untuk mengembangkan kemampuannya.

Accelarated Learning akarnya telah tertanam sejak jaman kuno (Accelarated Learning telah dipraktekkan setiap anak yang dilahirkan). Dalam penelitian otak modern 
Accelarated Learning menemukan kiasankiasan cara otak belajar, dan berusaha merancang lingkungan belajar yang efektif.

Beberapa asumsi pokok Accelarated Learning mengenai hal-hal yang dibutuhkan untuk mengoptimalkan pembelajaran adalah : (1) Lingkungan belajar yang positif. (2) Keterlibatan pembelajar sepenuhnya. (3) Kerjasama diantara siswa. (4) Variasi yang cocok untuk semua gaya belajar dan gaya berpikir. (5) Belajar kontekstual.

Menurut Walberg dan Greenberg yang dikutip DePorter (2004:19,374) lingkugan sosial adalah penentu psikologis utama yang mempengaruhi belajar akademis. Suasana ruangan menunjukkan arena belajar yang dipengaruhi emosi. Penelitian menunjukkan bahwa para siswa menyebut kualitas hubungan mereka dengan guru sebagai faktor paling utama dalam kaitannya dengan kenyamanan dalam belajar.

Penciptaan lingkungan belajar yang menyenangkan dan pembinaan hubungan yang harmonis antara guru dan siswa diharapkan mampu memunculkan emosi positif bagi siswa. Emosi yang positif ini sangat mempengaruhi keberhasilan siswa dalam belajar., karena berkaitan dengan cara kerja otak manusia yaitu sistem limbik. Sistem limbik berkaitan erat dengan emosi dan memori jangka panjang. Sistem limbik di dalam otak manusia berperan sebagai saklar yang menentukan otak mana yang aktif, otak reptil (pusat kendali; mengatur fungsi utama tubuh, insting, mengatur reaksi dalam keadaan bahaya) atau otak neo cortex (proses berpikir). Seseorang yang berada dalam keadaan tegang, stres, takut atau marah, akan meneruskan informasi yang diterima ke otak reptil, sehingga otak neo cortex tidak mampu berpikir. Sebaliknya, ketika seseorang dalam kedaan bahagia, tenang, rileks. maka otak neo cortex akan aktif dan digunakan untuk berpikir (Gunawan, 2004:24)

Lingkungan yang banyak memberikan tekanan mental dan stres akan sangat menghambat kinerja otak, sehingga siswa akan kesulitan untuk menyerap informasi yang disampaiakan oleh guru selama proses belajar mengajar. Goleman berpendapat, "Seseorang dapat berkonsentrasi paling baik saat mereka sedikit lebih dituntut dari biasanya, dan mereka dapat memberikan lebih dari biasanya. Jika tuntutan terlalu sedikit, orang akan menjadi bosan, jika tuntutan terlalu besar untuk diatasi, mereka akan menjadi cemas" (DePorter, 2004:23). Oleh karena itu, menjadi sangat penting bagi seorang guru untuk dapat menciptakan kondisi fisik maupun mental yang nyaman dan mendukung unntuk melakaukan aktivitas belajar bagi siswa.

Salah satu cara yang dapat dilakukan oleh guru antara lain, melakukan senam otak. Senam otak adalah serangkaian gerakan tubuh yang sederhana digunakan untuk semua bagian otak guna meningkatkan kemempuan belajar. Senam otak sangat baik dilakukan pada awal proses pembelajaran (Gunawan, 2006:270). Gerakan-gerakan sederhana latihan senam otak dapat menyeimbangkan kembali fungsi-fungsi otak (Frashing, 2007:179)

Gerakan senam otak yang sederhana antara lain : (1) gerakan silang, yaitu menggerakkan tangan kanan bersamaan dengan kaki kiri dan tangan kiri bersamaan dengan kaki kanan, bergerak ke depan, ke samping, ke belakang atau jalan di tempat, tangan menyentuh lutut yang berlawanan, (2) 8 tidur, yaitu membuat angka 8 tidur tiga kali tiap tangan, kemudian tiga kali dengan kedua tangan atau juga dapat dilakukan dengan menggunakan siku, (3) coretan ganda, yaitu menggambar dengan kedua tangan pada saat yang sama, ke dalam, ke luar, ke atas, ke bawah, (4) putaran leher, yaitu tundukan kepala ke depan dan pelan-pelan memutar leher dari satu sisi ke sisi lainnya lalu ulangi dengan bahu diturunkan, serta (5) mengisi energi, yaitu duduk di kursi dengan santai dan meletakkan dahi diantara kedua tangan di atas meja, tarik nafas sambil menegakkan kepala,

Pembelajaran secara ekspositori lebih sering dilakukan oleh guru karena sangat sederhana. Strategi pembelajaran Ekspositori merupakan strategi memberitahukan atau menjelaskan. Strategi pembelajaran Ekspositori menurut Sanjaya (2008:179) adalah strategi pembelajaran yang menekankan pada proses penyampaian materi secara verbal dari seorang guru kepada sekelompok siswa dengan maksud agar siswa dapat menguasai materi pelajaran secara optimal.

Strategi pembelajaran Ekspositori sering dihubungkan dengan kurangnya latihan dalam pembelajaran, menggunakan buku secara monoton, kekakuan penekanan pada pembelajaran berdasarkan fakta dan hafalan, menggunakan metode ceramah dan lain-lain. Sanjaya (2008 : 180 ) menjelaskan bahwa pembelajaran yang berbasis pada siswa secara umum diajukan sebagai antithesis strategi pembelajaran Ekspositori dimana pembelajar menjadi penerima pengetahuan. Strategi 
pembelajaran Ekspositori lebih cocok digunakan untuk mentransfer pengetahuan.

Strategi pembelajaran Ekspositori mengasumsikan ada bagian penting dari isi, keterampilan dan nilai yang diajarkan. Yaitu, pembelajaran berkaitan dengan kuliah, buku teks dan dokumen kurikulum lain yang menjadi pembelajaran inti dari kurikulum sekolah. Guru disiapkan untuk mengajar pelajaran penting ini kepada siswa. Mengajar diasumsikan sebagai proses tranmisi. Guru dan sumber belajar memiliki peranan utama dalam memindahkan informasi, keterampilan dan nilai dari sumber belajar kepada siswa. Akan tetapi, mengajar bukanlah hal yang monoton, belajar merupakan penyediaan informasi yang telah diproses sesuai dengan kepentingan dan kebutuhan. Informasi dan keterampilan untuk memperoleh informasi yang dianggap penting. Konsekuensinya, prestasi siswa diukur dari jumlah informasi yang mampu diingat atau seberapa efektif keterampilan yang dapat digunakan.Sanjaya (2008: 180)

Tujuan utama dari strategi pembelajaran Ekspositori adalah untuk mentransfer pengetahuan dan keterampilan kepada siswa. Dalam strategi pembelajaraan Ekspositori guru mengarahkan kegiatan belajar. Guru harus melihat apakah pembelajaran yang ditentukan sudah tercakup dan apakah siswa sudah menguasainya. Guru merupakan sumber penting dan komponen penting dalam tranmisi antara sumber pembelajaran dan pembelajar. Guru memutuskan buku sumber pembelajaran lain yang digunakan. Peran guru adalah untuk memandu siswa untuk memperoleh jawaban yang benar. Dalam strategi pembelajaran Ekspositori penjelasan dan arahan guru harus jelas. Pernyataan dan pertanyaan yang ambigu akan membingungkan siswa dan menjadi penghalang proses belajar siswa.

Terdapat beberapa karakteristik strategi pembelajaran Ekspositori. Pertama, strategi pembelajaran Ekspositori dilakukan dengan cara menyampaikan materi pelajaran secara verbal. Kedua, materi pelajaran yang disampaikan adalah materi pelajaran yang sudah jadi. Ketiga, tujuan utama pembelajaran adalah penguasaan materi pelajaran itu sendiri.Sanjaya (2008: 179)

Dalam strategi pembelajaran Ekspositori ada beberapa prinsip yang harus diperhatikan, yaitu : (1) berorientasi pada tujuan, (2) prinsip komunikasi, (3) prinsip kesiapan, dan (4) prinsip berkelanjutan (Sanjaya, 2008:179)
Dalam proses pembelajaran melatih siswa berpikir merupakan tujuan belajar yang sangat penting. Ketika seseorang membayangkan sesuatu atau berusaha memecahkan persoalan atau masalah, maka kegiatan ini disebut berpikir. Berpikir diperlukan dalam membuat keputusan dan memecahkan masalah. Menurut Ahmadi (2003) berpikir adalah aktivitas psikis yang intensional yang terjadi apabila seseorang menjumpai problema (masalah) yang harus dipecahkan. Sarbana dan Dina (2003) menyatakan bahwa gaya berpikir memungkinkan seseorang memiliki keragaman, keunikan yang berbeda dengan orang lain dengan menggunakan informasi yang diterimanya dan cara mengolahnya sebagai alat untuk mempertimbangkan dan mengambil keputusan. De Bono (2007) mendefinisikan berpikir sebagai keterampilan mental yang memadukan kecerdasan dengan pengalaman. Keterampilan berpikir menentukan bagaimana kecerdasan yang digunakan. Berpikir merupakan kegiatan untuk menemukan pengetahuan yang benar dengan menggunakan proses berpikir dalam menarik suatu kesimpulan yang berupa pengetahuan (Suryasumantri, 2005). Suryabrata (2010) menyatakan bahwa berpikir adalah meletakkan bagian pengetahuan yang diperoleh manusia. Pengetahuan yang dimaksud mencakup konsep, gagasan, dan pengertian yang dimiliki atau diperinci. Menurut Dryden dan Vos (2002) kemampuan manusia berpikir dikarenakan berfungsinya otak sebagai organ luar biasa yang terdiri dari triliun sel-sel yang saling bertukar informasi segingga memungkinkan manusia untuk bertindak sesuai dengan pikirannya.

Menurut DePorter dan Hernacki (1992) gaya berpikir adalah cara mengingat dan memperhatikan detail dengan mudah dan mengingat fakta-fakta, informasi spesifik, rumus-rumus dan berbagai peraturan dengan mudah. Sementara Tellier dalam DePorter dan Hernacki (1992) mengatakan bahwa gaya berpikir adalah cara yang konsisten yang dilakukan individu dalam mencari informasi, cara mengingat serta memikirkan cara penyelesaian suatu persoalan.

Tipe pemikir pada orang yang memiliki gaya berpikir sekuensial konkrit adalah berpikir realistis dan rasional berdasarkan perolehan yang mereka ketahui melaui indera fisik, baik indera penglihatan, peraba, pendengaran, perasa, maupun penciuman. Bila dikaitkan dengan dua fungsi belahan otak, maka otak 
kirilah yang mengatur pikiran secararealistis dan rasional, dengan kata lain orang yang memiliki gaya berpikir sekuensial konkrit cenderung menggunakan otak sebelah kiri lebih dominan dari sebelah kanan. Proses berpikir otak kiri bersifat logis, sekuensial, linier, dan rasional (DePorter dan Hernacki, 2003). Otak kiri lebih bersifat akademis dan memainkan peranan dalam pemerosesan logika, kata-kata, matematika, dan urutan. Otak kiri berpikir secara sekuensial, teratur, logis, dan runtut. Kerja otak kiri adalah keteraturan, kerapian, dan sesuatu yang pasti. Dengan demikian orang yang memiliki gaya sekuensial konkrit selalu memperhatikan dan mengingat realitas dengan mudah dan mengingat fakta-fakta, informasi, rumus-rumus, dan aturan-aturan khusus dengan mudah.

Berdasarkan karakteristik yang dimiliki, seseorang dengan gaya berpikir sekuensial konkrit adalah orang yang cenderung teratur dan rapi, biasanya selalu mempunyai catatan yang rapi, selalu tepat waktu, terencana, dan tidak suka hal-hal yang bersifat mendadak. Siswa yang memiliki gaya berpikir sekuensial konkrit biasanya menyenangi kerapian rambut, pakaian, buku dan alat tulis yang tertata dengan baik, bahkan mereka umumnya merasa terganggu jika melihat teman-temannya yang tidak rapi berpakaian atau meletakkan sesuatu benda yang tidak teratur. Dalam pembelajaran, kegiatan praktik adalah cara belajar yang terbaik bagi orang yang memiliki gaya berpikir sekuensial konkrit (Dryden dan Vos, 2002). Untuk belajar, catatan dan makalah merupakan cara terbaik yang dapat digunakan. Siswa dengan tipe ini harus mampu mengatur tugastugas menjadi proses tahap demi tahap dan berusaha keras untuk mendapatkan kesempurnaan pada tiap-tiap tahap. Tipe siswa ini juga menyukai pengarahan dan proses kerja khusus.

Menurut DePorter dan Hernacki (2003), untuk meningkatkan kemampuan berpikir pada tipe ini ada beberapa langkah yang dapat dilakukan, yaitu : (1) membangun kekuatan organisasi, yaitu mengatur minggu-minggu dan hari-hari secara realistis dengan merencanakan berapa lama waktu yang dibutuhkan untuk menyelesaikan suatu pekerjaan, (2) mengetahui berbagai detail yang diperlukan, yaitu segala sesuatu yang dibutuhkan untuk menyelesaikan suatu tugas, (3) membagi kegiatan menjadi langkah-langkah yang spesifik dalam beberapa tahap, yaitu menentukan pembagian waktu agar pekerjaan atau tugas tidak dilakukan dengan terburu-buru, dan (4) menyiapkan lingkungan kegiatan yang tenang, yaitu mengetahui segala sesuatunyang dapat mengganggu konsentrasi untuk selanjutnya gangguan-gangguan tersebut dimusnahkan.

Seseorang yang memiliki gaya berpikir sekuensial abstrak sangat menyukai dunia teori dan pikiran abstrak. Mereka suka berpikir konseptual dan menganalisis informasi. Gaya berpikir sekuensial abstrak bertipe pemikiran abstrak, berpikir konseptual dan menganalisis informasi. Tipe ini biasanya tidak mau menerima begitu saja segala informasi tanpa melakukan cek dan ricek. Mereka yang memiliki gaya berpikir sekuensial abstrak umumnya senang dengan dunia teori, segala sesuatu dihubungkan dengan teori yang mereka baca. Gaya berpikir sekuensial abstrak berpikir dalam sebuah konsep dan analisis informasi. Proses berpikir yang mereka miliki adalah logis, rasional, dan intelektual (DePorter dan Hernacki, 2003).

Seseorang yang memiliki gaya berpikir sekuensial abstrak lebih cenderung menggunakan otak sebelah kanan lebih dominan daripada otak sebelah kiri. Otak kanan lebih bersifat kreatif, biasanya memainkan peranan dengan hal-hal yang berhubungan dengan irama, musik, gambar, dan imajinasi. Proses berpikir otak kanan lebih bersifat acak, tidak teratur, intuitif, dan holistik. Cara berpikirnya sesuai dengan cara-cara untuk mengetahui hal yang bersifat nonverbal, seperti perasaan, emosi, kesadaran yang berkenaan dengan perasaan (merasakan kehadiran benda atau orang), kesadaran spasial, pengenalan bentuk dan pola, musik, seni, kepekaan warna, kreativitas, dan visualisasi (DePorter dan Hernacki, 2003).

Seseorang dengan gaya berpikir sekuensial abstrak sangat mudah mengetahui apa yang penting seperti poin-poin utama dan detail yang signifikan. Tipe gaya berpikir sekuensial abstrak biasanya lebih senang bekerja sendiri daripada berkelompok. Jika dikaitkan dengan cara belajar, maka aktivitas favorit mereka adalah membaca, dan jika sebuah pekerjaan memerlukan penelitian, mereka dengan sangat teliti dan mendalam, mereka ingin mengetahui sebab-sebab dibalik akibat.

Menurut DePorter dan Hernacki (2003), untuk meningkatkan kemampuan berpikir pada tipe sekuensil abstrak ada beberapa langkah yang dapat dilakukan yaitu : (1) melihat diri berpikir, yaitu ketika memecahkan masalah 
(masalah harus diubah menjadi situasi teoritis dan dipecahkan sesuai dengan situasi teoritis tersebut), (2) memperbanyak rujukan, yaitu ketika menyelesaikan suatu pekerjaan atau tugas, maka harus memperbanyak bacaan tentang sesuatu yang berkaitan dengan tugas yang akan diselesaikan sesuai dengan fakta dan standar, (3) mengupayakan keteraturan, yaitu memacu situasi yang teratur dengan cara membuat grafik (langkah-langkah dan waktu yang diperlukan untuk setiap langkah), dan (4) menganalisis orang-orang yang mempunyai hubungan dengan tipe pemikir sekuensial abstrak, yaitu saling memahami ketika menyelesaikan suatu tugas atau pekerjaan.

Dalam aplikasinya, untuk menentukan seseorang memiliki gaya berpikir sekuensial konkrit dan sekuansial abstrak digunakan tes baku yang diadaptasi oleh Tellier dalam DePorter dan Hernacki (1999). Tes tersebut terdiri atas lima belas item, dimana setiap item terdiri atas empat pilihan jawaban. Dan setiap responden diberi kesempatan untuk memilih dua dari empat pilihan yang tersedia. Jawaban yang diberikan oleh responden menunjukkan cara berpikir dan klasifikasi siswa. Dalam jawaban tersebut, tidak ada pilihan jawaban yang benar atau salah.

Rumusan masalah sebagai berikut : (1) Apakah hasil belajar bahasa Indonesia siswa yang diajarkan dengan strategi pembelajaran Accelerated Learning lebih tinggi dibandingkan dengan hasil belajar bahasa Indonesia siswa yang diajarkan dengan strategi pembelajaran Ekspositori ?; (2) Apakah hasil belajar bahasa Indonesia siswa yang memiliki gaya berpikir sekuensial konkrit lebih tinggi dibandingkan dengan hasil belajar Bahasa Indonesia siswa yang memiliki gaya berpikir sekuensial abstrak?; dan (3) Apakah terdapat interaksi antara strategi pembelajaran dengan gaya berpikir sekuensial dalam mempengaruhi hasil belajar bahasa Indonesia?

\section{METODE}

Tabel 1. Desain Eksperimen Faktorial 2 x 2
Penelitian ini akan dilaksanakan di MAN 1 dan MAN 2 Medan. Populasi dalam penelitian ini adalah seluruh siswa reguler kelas XI MAN 1 Medan masing-masing berjumlah 4 kelas yang terdiri dari 35 siswa setiap kelasnya dengan jumlah 140 orang, dan di sekolah MAN 2 Medan masing-masing berjumlah 4 kelas yang terdiri dari 35 siswa setiap kelasnya dengan jumlah 140 orang siswa. Teknik pengambilan sampel dilakukan dengan teknik cluster random sampling, selanjutnya melalui pengundian maka kelas $\mathrm{XI}_{3}$ MAN 1 Medan berjumlah 35 orang terpilih sebagai kelas yang diajar dengan strategi pembelajaran Accelarated Learning. Sedangkan siswa kelas $\mathrm{XI}_{4}$ MAN 2 Medan berjumlah 35 orang terpilih sebagai kelas yang diajar dengan strategi pembelajaran Ekspositori.

Sebelum dilakukan eksperimen, kedua kelas sampel terlebih dahulu diberi tes untuk mengetahui gaya berpikir siswa. Gaya berpikir dikategorikan atas kemampuan berpikir sekuensial konkrit dengan gaya berpikir sekuensial abstrak. Penelitian ini menggunakan metode eksperimen dengan rancangan quasi eksperimen disain faktorial $2 \times 2$. Metode penelitian ini digunakan karena kelas yang dipakai untuk perlakuan merupakan kelas yang sudah terbentuk sebelumnya atau tanpa mengubah situasi dan kondisi kelas yang sudah terbentuk.

Guru yang ditetapkan untuk melakukan pembelajaran dengan strategi pembelajaran Accelereted Learning maupun ekspositori diberikan petunjuk khusus mengenai cara dan langkah-langkah dalam penyajian materi pelajaran. Strategi pembelajaran Accelerated Learning dan strategi pembelajaran Ekspositori sebagai variabel bebas. Gaya berpikir sebagai variabel moderator dan hasil belajar bahasa Indonesia sebagai variabel terikat. Variabelvariabel tersebut selanjutnya akan ditinjau dalam penelitian dengan disain pada tabel $2 \times 2$ berikut :

\begin{tabular}{|l|c|c|}
\hline \multirow{2}{*}{ Gaya Berpikir $(\mathrm{B})$} & \multicolumn{2}{|c|}{ Strategi Pembelajaran $(\mathrm{A})$} \\
\cline { 2 - 3 } & Accelerated Learning $\left(\mathrm{A}_{1}\right)$ & Ekspositiri $\left(\mathrm{A}_{2}\right)$ \\
\hline Sekuensial Konkret $\left(\mathrm{B}_{1}\right)$ & $\mathrm{A}_{1} \mathrm{~B}_{1}$ & $\mathrm{~A}_{2} \mathrm{~B}_{1}$ \\
\hline Sekuensial Abstrak $\left(\mathrm{B}_{2}\right)$ & $\mathrm{A}_{1} \mathrm{~B}_{2}$ & $\mathrm{~A}_{2} \mathrm{~B}_{2}$ \\
\hline
\end{tabular}

Keterangan :

$\mathrm{A}_{1} \mathrm{~B}_{1}$ : Hasil belajar Bahasa Indonesia siswa yang diajar dengan strategi pembelajaran Accelerated Learning yang memiliki gaya berpikir sekuensial konkret 
$\mathrm{A}_{1} \mathrm{~B}_{2}$ : Hasil belajar Bahasa Indonesia siswa yang diajar dengan strategi pembelajaran Accelerated Learning yang memiliki gaya berpikir sekuensial abstrak

$\mathrm{A}_{2} \mathrm{~B}_{1}$ : Hasil belajar Bahasa Indonesia siswa yang diajar dengan strategi pembelajaran Ekspositori yang memiliki gaya berpikir sekuensial konkret

$\mathrm{A}_{2} \mathrm{~B}_{2}$ : Hasil belajar Bahasa Indonesia siswa yang diajar dengan strategi pembelajaran Ekspositori yang memiliki gaya berpikir sekuensial abstrak

Teknik analisa data yang digunakan adalah teknik statistik inferensial dan deskriptif. Teknik statistik deskriptif digunakan untuk mendeskripsikan data, antara lain : nilai ratarata (mean), median, modus, standar deviasi dan kecenderungan data. Teknik statisik inferensial digunakan adalah teknik analisa varians dua jalur dengan taraf signifikan 0,05.

Sebelum teknik ini digunakan perlu dilakukan uji persyaratan. Uji persyaratan yang dilakukan adalah uji normalitas menggunakan uji Lilliefors, sedangkan uji homogenitas digunakan uji Bartlett dan uji F dari Sudjana (1992). Karena ada perbedaan dan interaksi antara variabel maka analisis dilanjutkan dengan uji Scheffe. Uji Scheffe digunakan karena banyak data dalam setiap kolom dan baris tidak sama. Selanjutnya untuk keperluan pengujian hipotesis, maka hipotesis dirumuskan sebagai berikut :

Hipotesis Pertama

$\mathrm{H}_{\mathrm{o}}: \mu \mathrm{A}_{1}=\mu \mathrm{A}_{2}$

$\mathrm{H}_{1}: \mu \mathrm{A}_{1}>\mu \mathrm{A}_{2}$

Hipotesis Kedua

$$
\mathrm{H}_{\mathrm{o}}: \mu \mathrm{B}_{1}=\mu \mathrm{B}_{2}
$$$$
\mathrm{H}_{1}: \mu \mathrm{B}_{1}>\mu \mathrm{B}_{2}
$$

Hipotesis Ketiga

$$
\begin{aligned}
& \mathrm{H}_{0}: \mathrm{A}><\mathrm{B}=0 \\
& \mathrm{H}_{1}: \mathrm{A}><\mathrm{B} \neq 0
\end{aligned}
$$

\section{HASIL DAN PEMBAHASAN \\ Hasil}

Pengujian hipotesis dilakukan menggunakan teknik analisis varians (ANAVA). Untuk keperluaan analisis varians,

\begin{tabular}{|c|c|c|c|}
\hline \multirow{2}{*}{$\begin{array}{l}\text { Gaya Berpikir } \\
\text { (B) }\end{array}$} & \multicolumn{2}{|c|}{ Strategi Pembelajaran (A) } & \multirow{2}{*}{ Total } \\
\hline & Accelerated Learning $\left(\mathrm{A}_{1}\right)$ & Ekspositori $\left(\mathrm{A}_{2}\right)$ & \\
\hline $\begin{array}{l}\text { Sekuensial Konkrit } \\
\qquad\left(\mathrm{B}_{1}\right)\end{array}$ & $\begin{array}{l}\mathrm{n}_{\mathrm{A} 1 \mathrm{~B} 1}=21 \\
\bar{x}_{\mathrm{A} 1 \mathrm{~B} 1}=31,21 \\
\mathrm{SD}=2,45 \\
\Sigma x=656 \\
\Sigma x^{2}=20488\end{array}$ & $\begin{array}{l}\mathrm{n}_{\mathrm{A} 2 \mathrm{~B} 1}=17 \\
\bar{x}_{\mathrm{A} 2 \mathrm{~B} 1}=25,73 \\
\mathrm{SD}=3,01 \\
\Sigma x=438 \\
\Sigma x^{2}=11534\end{array}$ & $\begin{array}{l}\mathrm{N}_{\text {bar }}=38 \\
\bar{x}_{\text {tbd }}=28,73 \\
\mathrm{SD}=3,77 \\
\Sigma x=1092 \\
\Sigma x^{2}=32022\end{array}$ \\
\hline $\begin{array}{l}\text { Sekuensial Abstrak } \\
\left(\mathrm{B}_{2}\right)\end{array}$ & $\begin{array}{l}\mathrm{n}_{\mathrm{A} 1 \mathrm{~B} 2}=14 \\
\bar{x} \\
\mathrm{~A} 1 \mathrm{~B} 2=25,78 \\
\mathrm{SD}=3,17 \\
\Sigma x=361 \\
\sum x^{2}=9337\end{array}$ & $\begin{array}{l}\mathrm{n}_{\mathrm{A} 2 \mathrm{~B} 2}=18 \\
\bar{x}_{\mathrm{A} 2 \mathrm{~B} 2}=28,72 \\
\mathrm{SD}=2,98 \\
\Sigma x=517 \\
\Sigma x^{2}=15001\end{array}$ & $\begin{array}{l}\mathrm{N}_{\text {bar }}=32 \\
\bar{x}_{\text {tbk }}=27,37 \\
\mathrm{SD}=3,39 \\
\Sigma x=876 \\
\Sigma x^{2}=24338\end{array}$ \\
\hline Total & $\begin{array}{l}\mathrm{n}_{\text {totkol }}=35 \\
x_{\mathrm{AlB} 1}=29 \\
\mathrm{SD}=3,85 \\
\Sigma x=1015 \\
\Sigma x^{2}=29825\end{array}$ & $\begin{array}{l}\mathrm{N}_{\text {totkom }}=35 \\
\bar{x}_{\mathrm{A} 1 \mathrm{~B} 1}=27,27 \\
\mathrm{SD}=3,28 \\
\Sigma x=955 \\
\Sigma x^{2}=26535\end{array}$ & $\begin{array}{l}\mathrm{n}_{\mathrm{tot}}=70 \\
\bar{x}_{\mathrm{tot}}=28,14 \\
\mathrm{SD}=3.5 \\
\Sigma x=1970 \\
\sum x^{2}=56360\end{array}$ \\
\hline
\end{tabular}
data yang diperlukan dapat dilihat pada tabel 2 .

Tabel 2. Data Hasil Belajar Bahasa Indonesia Siswa

Hasil perhitungan ANAVA seperti yang ditunjukkan dalam tabel 3, yaitu rangkuman analisis faktorial $2 \times 2$.

Tabel 3. Rangkuman Analisis Faktorial 2x2 


\begin{tabular}{|c|c|c|c|c|c|c|}
\hline Sumber Varians & JK & $\mathrm{dk}$ & $\mathrm{RJK}$ & $\mathrm{F}_{\text {hitung }}$ & $\mathrm{F}_{\text {tabel }}$ & Kesimpulan \\
\hline Strategi Pembelajaran & 44,8 & 1 & 44,8 & 44,39 & 3,99 & Signifikan \\
Gaya Berpikir & 201,4 & 1 & 201,4 & 24,20 & 3,99 & Signifikan \\
Interaksi & 123,21 & 1 & 123,21 & 14,81 & 3,99 & Signifikan \\
\hline Antar kelompok & 369,41 & 3 & 123,13 & & & \\
Dalam kelompok & 549,16 & 66 & 8,32 & & & \\
\hline Total & 918,57 & 69 & & & & \\
\hline
\end{tabular}

Untuk mengetahui interaksi antara strategi pembelajaran dan gaya berpikir terhadap hasil belajar Bahasa Indonesia, maka dilakukan uji lanjut dengan Uji Scheffe.

Tabel 4. Rangkuman Uji Scheffe

\begin{tabular}{|l|c|c|c|}
\hline \multicolumn{2}{|c|}{ Hipotesis Statistik } & Qhitung & $Q_{\text {tabel }}(3,66) \alpha=0,05$ \\
\hline Ho: $\mu_{\mathrm{A} 1 \mathrm{~B} 1}=\mu_{\mathrm{A} 2 \mathrm{~B} 1}$ & $\mathrm{H}_{1}: \mu_{\mathrm{A} 1 \mathrm{~B} 1}>\mu_{\mathrm{A} 2 \mathrm{~B} 1}$ & 5,94 & 2,75 \\
\hline Ho: $\mu_{\mathrm{A} 1 \mathrm{~B} 1}=\mu_{\mathrm{A} 1 \mathrm{~B} 2}$ & $\mathrm{H}_{1}: \mu_{\mathrm{A} 1 \mathrm{~B} 1}>\mu_{\mathrm{A} 1 \mathrm{~B} 2}$ & 5,55 & 2,75 \\
\hline Ho: $\mu_{\mathrm{A} 1 \mathrm{~B} 1}=\mu_{\mathrm{A} 2 \mathrm{~B} 2}$ & $\mathrm{H}_{1}: \mu_{\mathrm{A} 1 \mathrm{~B} 1}>\mu_{\mathrm{A} 2 \mathrm{~B} 2}$ & 2,82 & 2,75 \\
\hline Ho: $\mu_{\mathrm{A} 2 \mathrm{~B} 1}=\mu_{\mathrm{A} 1 \mathrm{~B} 2}$ & $\mathrm{H}_{1}: \mu_{\mathrm{A} 2 \mathrm{~B} 1}<\mu_{\mathrm{A} 1 \mathrm{~B} 2}$ & 0,22 & 2,75 \\
\hline Ho: $\mu_{\mathrm{A} 2 \mathrm{~B} 1}=\mu_{\mathrm{A} 2 \mathrm{~B} 2}$ & $\mathrm{H}_{1}: \mu_{\mathrm{A} 2 \mathrm{~B} 1}>\mu_{\mathrm{A} 2 \mathrm{~B} 2}$ & 2,98 & 2,75 \\
\hline Ho: $\mu_{\mathrm{A} 2 \mathrm{~B} 2}=\mu_{\mathrm{A} 1 \mathrm{~B} 2}$ & $\mathrm{H}_{1}: \mu_{\mathrm{A} 2 \mathrm{~B} 2}>\mu_{\mathrm{A} 1 \mathrm{~B} 2}$ & 2,91 & 2,75 \\
\hline
\end{tabular}

Hasil pengujian lanjut di atas, menunjukkan adanya interaksi antara strategi pembelajaran dan gaya berpikir sekuensial terhadap hasil belajar Bahasa Indonesia siswa MAN 1 dan MAN 2 Medan. Interaksi strategi pembelajaran dan gaya berpikir dapat ditunjukkan seperti pada gambar berikut:

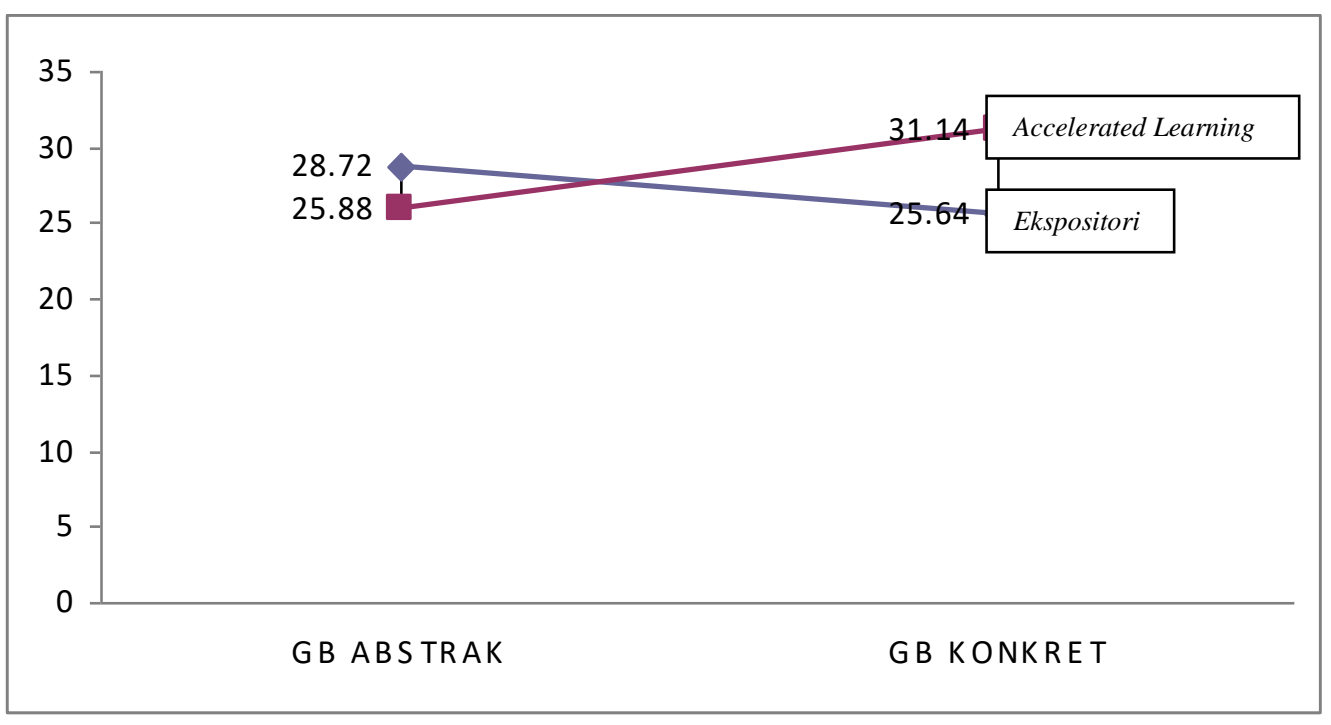

Gambar 1. Interaksi Strategi Pembelajaran dan Gaya Berpikir Sekuensial

\section{PEMBAHASAN}

Hasil belajar Bahasa Indonesia siswa yang dibelajarkan dengan strategi Accelerated Learning lebih tinggi daripada hasil belajar siswa yang diajarkan dengan strategi pembelajaran Ekspositori dapatlah diterima. Hasil penelitian ini mendukung teori yang dikemukakan oleh Nggermanto ( 2001) Accelarated Learning dapat didefinisikan sebagai pemberdayaan siswa untuk belajar lebih cepat, lebih efektif dan lebih menyenangkan. Accelarated Learning disebut juga Cara Belajar Cepat (CBC) yang merupakan sebuah upaya yang meningkatkan kualitas pendidikan siswa 
agar dapat belajar lebih cepat, mengingat lebih banyak dan berfikir lebih kreatif (Rose dan Nicholl, 2002:8) Meier (2003:26) juga mengungkapkan bahwa "Accelarated Learning adalah pendekatan belajar yang paling maju yang digunakan pada masa sekarang, dan mempunyai banyak manfaat. Accelarated Learning didasarkan pada penelitian mutakhir mengenai otak dan belajar yang dapat menggunakan berbagai metode dan media. Bersifat terbuka dan luwes dimana pembelajar diajak sepenuhnya. Accelarated Learning cocok dengan semua gaya belajar dan memberi energi dalam proses belajar. Accelarated Learning membuat belajar menyenangkan dan benarbenar mementingkan hasil, hasil dan hasil. DePorter (2004:14) menyatakan bahwa Accelarated Learning dapat memungkinkan siswa untuk belajar dengan kecepatan yang mengesankan dengan upaya yang normal dan dibarengi kegembiraan. dimana Accelarated Learning berusaha mengubah suasana kelas secara total dan berusaha memadukan musik, permainan, warna, cara belajar positif, dan suasana belajar yang menyenangkan sehingga kegiatan pembelajaran menjadi lebih bermakna dan menyenangkan dengan daya ingat yang kuat.

Accelarated Learning didasarkan pada teori pemerosesan informasi. Aspek yang berperan penting dalam pemerosesan informasi adalah aspek kognitif. Aspek ini berkaitan dengan intelektual dan intelegensi, kemampuan intelegensi itu bersifat relatif. Kemampuan ini harus dikembangkan secara optimal untuk memperoleh kesuksesan hidup, namun kesuksesan hidup juga tidak semata-mata ditentukan oleh kemampuan intelegensi, karena ada faktor kemampuan lain yang turut mempengaruhi. (Darmawan 2009: 127)

Jika dikaitkan dengan kegiatan pembelajaran bahasa Indonesia, strategi Accereted Learning yang diterapkan mengakomodasi berbagai pendekatan yang digunakan untuk membentuk suatu rangkaian kegiatan pembelajaran, seperti tata cara kerja, pencitraan, dan mengakomodir semua gaya belajar dan gaya berpikir. Langkah-langkah pembelajaran bahasa Indonesia menggunakan strategi pembelajaran Accelerated Learning dengan empat tahap pembelajaran adalah : (1) tahap persiapan (preparation), (2) tahap penyampaian (Presentation), (3) tahap pelatihan (practice) dan (4) tahap penampilan hasil (performance).
Strategi pembelajaran Accelerated Learning menuntut keaktifan siswa terutama pada tahap pelatihan dan penampilan. Strategi pembelajaran Accelerated Learning tidak hanya proses dalam menyampaikan materi saja tetapi juga melibatkan proses pelatihan. Dalam pembelajaran bahasa Indonesia Strategi Accelerated Learning dapat mendorong siswa untuk aktif belajar karena siswa dapat saling berdiskusi, bekerjasama, bertukar pendapat dalam mempelajari materi ajar. karena itu peran guru dalam pembelajaran Accelerated Learning sebagai fasilitator yang mengarahkan siswa untuk menemukan dan mengkonstruk sendiri pengetahuannya.

Hal ini sesuai dengan temuan penelitian yang terdahulu yaitu Penelitian yang dilakukan Ruslan (2006) menyimpulkan bahwa siswa yang memiliki gaya berpikir sekuensial konkrit yang dibelajarkan dengan model pembelajaran berbasis masalah Memperoleh hasil belajar kimia yang lebih tinggi dibandingkan dengan siswa yang memiliki gaya belajar sekuensial abstrak yang dibelajarkan dengan metode yang sama. Dan penelitian yang dilakukan Nelfiza (2009) di SMPN 2 Tebing Tinggi menyimpulkan bahwa siswa yang memiliki gaya berpikir sekuensial konkrit yang dibelajarkan dengan strategi pembelajaran Inkuiri akan memperoleh hasil belajar Bahasa Inggris yang lebih tinggi dibandingkan dengan siswa yang memiliki gaya belajar sekuensial Abstrak yang dibelajarkan dengan strategi pembelajaran yang sama.

Pengujian hipotesis yang kedua ini menunjukkan bahwa hasil belajar Bahasa Indonesia dari siswa yang memiliki gaya berpikir Sekuensial Konkret lebih tinggi daripada hasil belajar Bahasa Indonesia dari siswa yang memiliki gaya berpikir Sekuensial Abstrak. Hasil ini membuktikan bahwa gaya berpikir Sekuensial Konkrit signifikan untuk membedakan hasil belajar Bahasa Indonesia. Gaya berpikir dalam penelitian ini dibedakan atas gaya berpikir Sekuensial Konkret dan gaya berpikir Sekuensial Abstrak. Dari hasil analisis data secara keseluruhan diperoleh rata-rata hasil belajar siswa dengan gaya berpikir Sekuensial Konkret lebih tinggi dari hasil belajar siswa dengan gaya berpikir Sekuensial Abstrak. Hal ini berindikasi bahwa siswa yang dengan gaya berpikir Sekuensial Konkret secara rata-rata mempunyai hasil belajar Bahasa Indonesia yang lebih tinggi dibanding siswa dengan gaya berpikir Sekuensial Abstrak. Dengan demikian siswa dengan gaya berpikir Sekuensial Konkret 
lebih memahami dan menguasai materi pelajaran Bahasa Indonesia dibandingkan siswa dengan gaya berpikir Sekuensial Abstrak. Hal ini didukung oleh teori (DePorter dan Hernacki, 2003) yang menyatakan orang yang memiliki gaya sekuensial konkrit selalu memperhatikan dan mengingat realitas dengan mudah dan mengingat fakta-fakta, informasi, rumus-rumus, dan aturan-aturan khusus dengan mudah.

Pengujian hipotesis yang ketiga terdapat interaksi antara strategi pembelajaran dan gaya berpikir sekuensial dalam mempengaruhi hasil belajar Bahasa Indonesia siswa MAN 1 Medan. Apabila dilihat dari rata-rata nilai hasil belajar Bahasa Indonesia kelompok siswa dengan gaya berpikir Sekuensial Konkrit dan dibelajarkan dengan strategi Accelerated Learning lebih baik dibandingkan dengan rata-rata hasil belajar Bahasa Indonesia kelompok siswa dengan gaya berpikir Sekuensial Konkrit yang dibelajarkan dengan strategi Ekspositori. Kemudian rata-rata hasil belajar Bahasa Indonesia kelompok siswa dengan gaya berpikir Sekuensial Abstrak yang dibelajarkan dengan strategi Ekspositori lebih tinggi dibandingkan dengan rata-rata hasil belajar Bahasa Indonesia kelompok siswa dengan gaya berpikir Sekuensial Abstrak yang dibelajarkan dengan strategi Accelerated Learning .

Hal ini bermakna bahwa bagi kelompok siswa dengan gaya berpikir Sekuensial Abstrak lebih baik menggunakan strategi pembelajaran Ekspositori dibandingkan dengan strategi pembelajaran Accelerated Learning, walaupun perbedaannya tidak terlalu signifikan. Dengan demikian dapatlah ditarik kesimpulan bahwa strategi pembelajaran dan gaya berpikir sekuensial cukup signifikan mempengaruhi hasil belajar Bahasa Indonesia siswa.

Semua hipotesis penelitian yaitu: (1) hasil belajar Bahasa Indonesia siswa yang dibelajarkan dengan strategi pembelajaran Accelerated Learning lebih tinggi daripada hasil belajar siswa yang dibelajarkan dengan strategi pembelajaran Ekspositori, (2) hasil belajar siswa dengan gaya berpikir Sekuensial Konkrit lebih tinggi daripada hasil belajar siswa dengan gaya berpikir Sekuensial Abstrak dan (3) terdapat interaksi antara strategi pembelajaran dan gaya berpikir sekuensial siswa dalam memberikan pengaruh terhadap hasil belajar Bahasa Indonesia siswa, ketigatiganya dapat diterima.

\section{PENUTUP}

Simpulan
Berdasarkan pengolahan data dan pembahasan terhadap hasil penelitian yang dikemukakan sebelumnya maka dalam penelitian ini dapat disimpulkan bahwa :

1. Hasil belajar Bahasa Indonesia siswa yang dibelajarkan dengan menggunakan strategi pembelajaran berbasis Accelarated Learning lebih tinggi dari hasil belajar Bahasa Indonesia siswa yang dibelajarkan dengan menggunakan Strategi Pembelajaran Ekpositori.

2. Hasil belajar Bahasa Indonesia siswa yang memiliki gaya berpikir sekuensial Konkrit lebih tinggi daripada hasil belajar Bahasa Indonesia siswa yang memiliki gaya berpikir sekuensial abstrak

3. Terdapat interaksi antara penggunaan Strategi Pembelajaran dan Gaya Berpikir sekuensial dalam mempengaruhi hasil belajar Bahasa Indonesia siswa.

\section{Saran}

Berdasarkan simpulan dan implikasi seperti yang telah dikemukakan maka disarankan beberapa hal sebagai berikut :

1. Dalam upaya peningkatan hasil belajar Bahasa Indonesia, maka guru yang mengasuh mata pelajaran Bahasa Indonesia disarankan agar menggunakan strategi pembelajaran yang tepat dan variatif dalam menyajikan materi dan aplikasi Bahasa Indonesia dalam kegiatan pembelajaran di kelas.

2. Disarankan kepada guru agar memperhatikan karakteristik siswa khususnya Gaya Berpikir yang dimiliki siswa sehingga dapat berpengaruh pada hasil belajar siswa.

3. Disarankan kepada pihak pengambil kebijakan dilingkungan MAN 1 dan MAN 2 Medan untuk mengadakan pelatihan bagi guru-guru tentang penggunaan Strategi Pembelajaran yang tepat dan dapat dijadikan alternatif dalam menyampaikan materi melalui (MGMP) Musyawarah guru mata pelajaran, untuk pembelajaran bahasa Indonesia yang lebih baik.

4. Guna penelitian lebih lanjut pada penggunaan strategi pembelajaran disamping guru yang menjadi mitra peneliti, perlu disosialisasikan terlebih dahulu kepada siswa bagaimana tahapan strategi pembelajaran sehingga peggunaan waktu dapat dimaksimalkan seefisien mungkin 
serta efektifitas pembelajaran dapat tercapai.

\section{DAFTAR PUSTAKA}

Ahmadi. 2003. Psikologi Umum, Jakarta: Rineka Cipta.

Anderson, OW, Krathwohl.2001. A Taxonomi for learning, Teaching and Assesing. New York: Addison Wesley Longman

Arikunto, Suharsimi. 2008. Dasar - Dasar Evaluasi Pendidikan, Jakarta: Bumi Aksara.

Budiningsih, 2005. Belajar dan Pembelajaran. Jakarta : PAU Depdiknas

B.Uno, Hamzah.2009.

Model

Pembelajaran.Jakarta: Bumi Aksara

Brown, H. dauglas, 2000. Principles of Learning and Teaching. New York: Logman.

Darmawan,Deni.2009.Komunikasi Pembelajaran Berbasis Brain.Bandung: Humaniora

Deporter, B dan Hernacki, M, 2004. Quantum Learning Alih Bahasa : Ary Nilandari. Bandung : Kaifa.

Deporter, B., Reardon, M., dan Sarah, S. (2004). Quantum Teaching. Bandung : Kaifa.

Dimiyati\&Mujiono.(2000).Belajar dan pembelajaran.Jakarta : Rineka Cipta.

Dryden G, Vos J. 2002. Revolusi Cara Belajar. Bandung: Kaifa

Gagne, R.M. 1977. The Condition of Learning. New York Holt Rinehart and Winston.

Gagne, Robert M, dan Briggs, Leslie. 1979. Principles of Instruction Design. New York : Holt Rinehart and Winston.

Gay, L.R. 1981. Educational Research. USA. Charles E. merril Publishing.

Hamalik, O, 1993. Mengajar azas, Metode dan Teknik. Bandung : Pustaka Mariana

Meier, Dave, 2003. The Acclerated Learning Hand Book. Jakarta : Kaifa. Instruction
Theories in Action .Reigeluth (ed). New Jersey : Lawrence Erlbaum As.

Merrill,MD. 1991. "A Lesson Based On The Component Display Theory"Instruction Theorys In action. New Jersey : Lawrence

Miarso, Yusuf Hadi, 2004. Menyemai Benih Teknologi Pendidikan. Jakarta: Perdana Media.

Miller, JhonP and Seller, Wayney. 1985. Curriculum: Perpective and practice. Logman : New York

Nggermanto, Agus. 2001. Quantum Quotient (kecerdasan quantum). Bandung: Nuansa

Prashnig, Barbara.2007.The power Of Learning styles. Bandung: Kaifa

Romizwoski, A.J. 1981. Instructional Design System, Decision making in course planning and Curriculum Design. London : Kogan

Reigeluth, C.M. 1983. Instructional Design Theories and Models: An Overviews Their Current Status. London : Lowrence Rrl Gaum Associates.

Reynolds, David. 2008. Effective Teaching. Yogyakarta. Pustaka pelajar

Rose and Nichoo, 2002. Accekerated Learning for The $21^{\text {th }}$ Century, Alih Bahasa: Dedi Ahimsa. Bandung: Nuansa Cendikia

Sadiman, A.M. 2003. Interaksi dan Motivasi Belajar Mengajar. Jakarta: Grafindo.

Sanjaya,Wina.2008. Strategi Pembelajaran Berorientasi Standar Proses Pendidikan. Jakarta: Kencana.

Sarbana dan Dina (2003). Ampuh Menjadi Cerdas Tanpa Batas. Jakarta : alex Media Komputindo

Suria Sumantri, Jujun, 2005. Falsafat Ilmu, Jakarta : Pustaka Sinar Harapan.

Wrightsman, Sigelman, Sanford. 1979. Psychology a Scientific Study of Human Behavior. California: Brooks/ Cole Publishing Company. 